\title{
Incorporating Video-Mediated Reflective Tasks in MATESOL Programs
}

\section{Caroline Payant}

Unlike the observed trends in general teacher education, the use of videos as a reflective tool with preservice English as a Second Language (ESL) teachers remains underexplored in MATESOL (Master of Arts in Teaching English to Speakers of Other Languages) programs. The present qualitative study examined how 5 nonnative-speaking preservice teachers used the videos of their own microteaching performances to mediate their reflective practices. The results from the qualitative analysis of the participants' post-microteaching reflective reports showed that they used videos to explore their professional and non-native identities, practical knowledge base, and pedagogical knowledge base. The results are discussed with respect to their implications for educational practice with preservice ESL teachers.

Contrairement aux tendances générales observées dans la formation des enseignants, l'emploi des vidéos comme outils de réflexion lors de la formation d'enseignants d'anglais langue seconde (ALS) n'a pas fait l'objet d'étude dans le cadre des programmes de maitrise en enseignement de l'anglais aux apprenants étrangers (MATESOL). L'étude qualitative présente porte sur l'emploi qu'ont fait 5 enseignants de langue maternelle étrangère en formation de vidéos de leur microenseignement comme outils d'intervention auprès de leurs pratiques réflexives. Les résultats de l'analyse qualitative des rapports réflexifs rédigés par les participants après leur microenseignement indiquent qu'ils se servent des vidéos pour explorer leurs identités comme professionnels et locuteurs étrangers, ainsi que leur base de connaissances pratiques et pédagogiques. On discute des résultats par rapport à leur incidence sur la pratique éducative des enseignants d'ALS en formation.

What teachers know and believe before they enter the classroom has been shown to impact their pedagogical decisions and actions (Borg, 2003; Freeman \& Johnson, 1998). To promote the adoption of informed approaches to pedagogy based on preservice teachers' experiences, reflective approaches have become widespread (Farrell, 2007; Jay \& Johnson, 2002; Loughran, 2002; Richards \& Farrell, 2011; Richards \& Lockhart, 1996; Zeichner \& Liston, 1996). With technological advances, the general field of education has witnessed a surge of interest in the use of personal videos to mediate teacher reflec- 
tion and professional growth (see, e.g., Tripp \& Rich, 2012, for a discussion). Videos have been used as tools for teacher training in authentic classrooms and in artificial teaching settings, namely teaching practice courses wherein preservice teachers implement microlessons for their peers. Although there is growing evidence that videos foster teachers' reflective practices, the majority of the research has focused on content-area teachers who are, for the most part, native speakers of English (Borko, Jacobs, Eiteljorg, \& Pittman, 2008; Calandra, Gurvitch, \& Lund, 2008; Collins, Cook-Cottone, Robinson, \& Sullivan, 2005; Sherin \& van Es, 2005; van Es \& Sherin, 2010). We therefore have a narrow understanding of how preservice English as a Second Language (ESL) teachers pursuing graduate degrees utilize videos to mediate the process of reflecting on their teaching practices. Importantly, in the field of Teaching English to Speakers of Other Languages (TESOL), a growing number of preservice teachers are non-native English speakers. Given the diverse cultural and linguistic backgrounds of students in graduate TESOL programs, it is worth examining how videos of preservice teachers' own teaching performances mediate reflective practices. The aim of this study is to fill a perceived gap by investigating how non-native, preservice ESL teachers, registered in a teaching practicum course I was teaching, use videos of their own microteaching performances for reflective purposes in a structured practicum seminar during the course of one semester. To situate the present study, I begin with a brief overview of historical perspectives of reflective practices. I then discuss trends in the field of education for incorporating reflective practices and video-mediated tasks. Finally, drawing on studies from the field of second language (L2) education, I show an important gap in our knowledge base about the use of video-mediated reflective tasks with preservice ESL teachers.

\section{Reflective Practices: A Brief History}

The origins of reflective teaching can be traced to the work of John Dewey (1933), who defined reflective teaching as an "active, persistent, and careful consideration of any belief or supposed form of knowledge in the light of the grounds that support it and the further conclusions to which it tends" (p. 9). He argued that reflective practices would free teachers from impulsive and thoughtless actions. From his viewpoint, rational and systematic thoughts require three integral qualities: open-mindedness, wholeheartedness, and intellectual responsibility. With these qualities, teachers can attend to alternative decisions, actions, and beliefs that enable the ongoing reorganization of their experiences. Dewey's views, however, inadvertently created a divide between theory and practice. In studying practitioners' professional knowledge, Schön (1983) argued that knowledge is not a product of "instrumental problem solving made rigorous by the application of scientific theory and technique" (p. 21). Teachers should be able to tap into the process of 
knowledge creation by examining their own practices. In his view, reflection operates in two distinct temporal frames: reflection-in-action and reflectionon-action (Schön, 1987; emphasis added). Reflection-in-action takes place in the classroom as teaching events unfold. It includes instances where teachers alter their actions in response to experiences that are unique or that contain an element of surprise. Reflection-in-action is marked by three features: reflection (a) is a conscious process, although not necessarily articulated in words; (b) has a critical function; and (c) gives rise to on-the-spot action. Reflection-on-action includes instances of reflection occurring before and/or after actions. Teachers frame and reframe situations, examine their teaching from different angles, and can uncover tacit and implicit knowledge about their pedagogy (Griffiths, 2000). Killion and Todnem (1991) proposed a third type of reflection, namely reflection-for-action. This, they claim, is the desired outcome of combining reflection-in- and -on-action. From this perspective, the goal of reflective practices is to use past experiences and emerging awareness of metacognitive knowledge to inform future practices. Reflectionfor-action, rather than privileging retrospective reflection, orients reflection toward the future.

Pennington (1992) introduced reflective approaches into the field of L2 teacher education, which were rapidly endorsed in L2 teacher education circles with preservice ESL teachers (Farrell, 2007; Richards \& Farrell, 2011; Richards \& Lockhart, 1996). Practice teaching in TESOL programs can include teaching opportunities in authentic ESL classrooms under the guidance and supervision of a cooperating teacher (Payant \& Murphy, 2012) or microteaching opportunities in artificial language classrooms under the supervision of a university-based instructor to fellow preservice teachers. In the present study, given that the preservice ESL teachers' reflective practices were based on their own microteaching events in a teaching practicum seminar with their peers (preservice teachers from a variety of linguistic and cultural backgrounds), the next section reports on microteaching events in similar settings.

Microteaching events offer preservice teachers the experience of developing and teaching an abridged version of a lesson to their peers. While microteaching, the fellow students assume dual roles: that of language learners and of learners of teaching. After the microlesson, the fellow students offer constructive feedback. The preservice teacher is then encouraged to incorporate that feedback into a revised lesson plan and to reteach the lesson to ESL learners (authentic classroom) or to their fellow students (artificial). The affordances and limitations of microteaching are well documented in the literature from preservice and teacher educators' perspectives (Amobi, 2005; Bell, 2007; Benton-Kupper, 2001; Kpanja, 2001; Mergler \& Tangen, 2010; Richards \& Farrell, 2011). Reported advantages include the opportunity to (a) develop short and focused lessons, (b) try new ideas in a safe environment, (c) receive feedback, and (d) reteach a modified lesson. An important limita- 
tion is the decontextualized nature of the experience. As a result, preservice teachers tend to struggle with the task of teaching to an imagined/artificial group of learners (Bell, 2007; He \& Yan, 2011; Richards \& Farrell, 2011) and may develop materials, learning objectives, and discourse practices that are only marginally appropriate for the intended audience.

To enrich the microteaching experience, Roberts (1998) proposes a reflective approach: in addition to developing and teaching a lesson, preservice teachers engage in collaborative post-microteaching reflections that enable reflection-on-action and -for-action (Killion \& Todnem, 1991; Schön, 1983). Drawing on teacher supervision models (Bailey, 2006), optimal approaches to reflective teaching are those that instill long-term, independent reflective practices. Despite the essential benefits of collaborative approaches to reflection, it is equally important for preservice teachers to learn about tools for self-reflection. In other words, given the isolated nature of classroom teaching, it is imperative that preservice teachers not rely solely on their peers and mentors for feedback about their teaching (Miyata, 2002); rather, preservice teachers need to develop reflective tools and practices that will help them assess their own teaching in future settings.

\section{Exploring Our Teaching Practices: Video-recordings}

Over the last two decades, the use of video in teacher education with preservice teachers headed for K-12 classrooms has become a common practice (Brophy, 2004; Miyata, 2002; Tripp \& Rich, 2012). In their review of the available literature, Tripp and Rich (2012) identified six key dimensions of video-facilitated research: types of reflection tasks, facilitation of reflection tasks, nature of collaborations, length of videos, number of reflections, and measurements of the impact of reflections on teaching.

Overall, affordances of videos appear to outweigh potential limitations. First, given the elusive nature of classroom teaching, videos provides valuable input for teachers by capturing what unfolded in real time and making some of the captured dimensions of the teaching events more permanent (Borko et al., 2008; Cullen, 1991; Sherin, 2004; Storeygard \& Fox, 1995; Zhang, Lundeberg, Koehler, \& Eberhardt, 2011). Furthermore, videos can be viewed on repeated occasions (Storeygard \& Fox, 1995; Zhang et al., 2011). This may help preservice teachers gain in-depth insights about their teaching, and is useful for further, more focused reflections on what actually transpired during the microteaching (Sherin, 2004). Videos also help preservice teachers attend to the quantity of teacher talk, the clarity of the instructions, and the provision of feedback/praise (Tripp \& Rich, 2012). Videos enable teachers to focus on their own teaching practices but also redirect their attention to their learners' needs and interaction patterns (Sherin \& van Es, 2005, 2009; van Es \& Sherin, 2010). Participants also appear to have a heightened critical awareness of teaching practices, an increased understanding of situated learning, 
and a clearer notion of lesson planning (Masats \& Dooly, 2011). Research also shows that reflective prompts and guiding principles enhance systematic reflective practices (Calandra et al., 2008; Collins et al., 2005; Miyata, 2002).

Video-mediated reflective practices do, however, have some limitations. In some cases, it causes some anxiety (Masats \& Dooly, 2011). Another limitation lies in the artificiality of the recording. Sherin (2004) explains that, unlike live observations, cameras are unable to capture fluid dimensions of classroom interactions: they are static and cannot easily change focus to capture multiple aspects of classroom dynamics. Finally, videos focus on the here-and-now and leave out important contextual information about what occurred in previous meetings. Despite these potential drawbacks, the use of videos as a tool to mediate reflective practices is on the rise and appears to have numerous affordances.

\section{Reflective Practice in Preservice ESL Teacher Education}

Although the practice of using videos in the general field of education is on the rise (for a review, see Tripp \& Rich, 2012), an examination of research with ESL teachers reveals a dearth of studies focusing on non-native-speaking preservice teachers using videos as a reflective tool. To date, researchers have examined collaborative video-mediated viewings and reflections with in-service teachers. For instance, in Laycock and Bunnag (1991), experienced secondary teachers taught classes in small groups $(N=6-8)$ and collaboratively viewed their teaching videos. After noting some shortcomings of unguided video viewings, the authors devised viewing guides that were found to help focus their participants' discussions and reflections. In another study, Baecher, Rorimer, and Smith (2012) examined the benefits of collaborative viewing with seven in-service teachers working in a public high school with English-language learners. Here the participants collaboratively viewed short clips of one another's teaching performances. They found that teachers moved away from evaluative comments to nonjudgmental observations of their teaching pedagogies.

Work with in-service teachers suggests that collaboration fosters teacher self-awareness. Video-mediated reflections have also been incorporated in preservice teacher education programs. Akcan (2010) examined collaborative viewings of teaching performance between preservice EFL teachers $(N=27)$ and their university-based practicum instructor. The qualitative analysis revealed increased awareness of actual teaching practices and use of English as well as an understanding of their students' behaviours. Savas (2012) examined preservice teachers' $(N=40)$ beliefs regarding the effectiveness of microteaching videos. Questionnaire data indicated that, overall, participants felt using videos helped them improve various aspects of their English proficiency skills, particularly as related to speaking and pronunciation skills. In addition to experiencing linguistic benefits, the majority of 
the participants felt that viewing their videos provided them with insights regarding instruction-giving practices and classroom management practices. With technological advances, collaborative efforts have also been facilitated through asynchronous communication. Liu (2012) compared preservice and in-service EFL teachers' use of videos in a virtual community. The participants discussed preservice and in-service teachers' videos via asynchronous discussion boards. Through semistructured interviews, questionnaire data, and monthly journal entries, Liu identified differences between these two groups of teachers in terms of the frequency of postings and the contents of discussions. The findings from the first two months of the data collection process revealed that the preservice teachers' postings tended to dominate the forum and their contents focused more frequently on describing, evaluating, and interpreting events compared to the postings of experienced peers. Conversely, the more experienced teachers tended to critique teaching events and to set up discussion topics. However, the focus of the online interactions between the two groups of participants fell in greater alignment over time as the newcomers became socialized into the discursive practices of the more experienced teachers. Finally, the use of videos was perceived by all as a professional learning opportunity in that they could virtually visit other teachers' classrooms and join a larger professional education community in their country.

In sum, growing empirical evidence gathered from the general field of education and, to a lesser extent, from the field of preservice ESL teacher education, shows that videos enrich and expand teachers' knowledge base. However, it is surprising that educators working with ESL and EFL teachers/ researchers seldom report on the use of videos despite these tools being readily available to most preservice teachers. The present study thus investigated preservice ESL teachers' video-mediated reflective practices. Specifically, by analyzing the mandatory post-microteaching reflection reports of non-native preservice ESL teachers, I examined which aspects they attended to while watching their own teaching videos. The research question that guided the present study is "What aspect(s) of their teaching practice do preservice ESL teachers focus on while viewing their recorded microteaching?"

\section{The Study}

\section{Context of the Practicum Course}

The study took place at a small institution in the Pacific Northwest of the United States. The preservice ESL teachers were registered in a two-year MATESOL program. In this program, preservice teachers are required to complete courses that focus on pedagogy and linguistic theory. Two instrumental pedagogical courses are a teaching methodology course and an ESL teaching practicum. In each of these courses, preservice teachers develop and 
teach microlessons to their classmates. The data from the present study were produced by the practicum students during their teaching practice course, and written records were used for analysis.

The teaching practicum consisted of two core components: one 3-hour weekly seminar and two 2-hour weekly ESL classroom observations over two 8-week periods. I, as the university-based practicum instructor, teach the weekly seminar, and I assign a variety of tasks to the preservice teachers: (a) complete readings about language-teaching pedagogy; (b) lead discussions to increase their pedagogic content knowledge; (c) share weekly ESL classroom observation reports; (d) develop and implement two 25-30 minute microteaching lessons about core English skills (speaking, writing), which were video-recorded; and (e) write two mandatory post-microteaching reflections to be shared only with me, the instructor.

In the ESL classroom, the preservice teachers worked with their assigned cooperating teacher (an experienced, in-service ESL teacher) and interacted with the ESL students. In this context, students were registered in an academic program (Intensive English Program), and class sizes ranged between 6 and 15 ESL students from various linguistic backgrounds (Arabic, Chinese, Japanese, Korean). The preservice teachers were initially engaged in nonparticipatory observations; their primary role was observing the ESL classrooms. Over the course of the 8-week sessions, the preservice teacher began assisting the cooperating teacher with small group discussions and taught, at minimum, one lesson. To support their ongoing reflective practices, the preservice teachers wrote weekly observation reports and shared these with the university-based practicum instructor.

\section{Participants and Data Collection}

The participants were the five non-native speakers registered in the graduate teaching practicum course, who were from a variety of linguistic and cultural backgrounds: China (2), Japan (1), and Taiwan (2). ${ }^{1}$ At the time of the study, they had limited experiences teaching English as a second/foreign language. Specifically, only one of the five participants had EFL teaching experience and one worked as a language tutor, teaching Japanese to American students. I served as both researcher and practicum instructor. In the role of practicum instructor, I provided written feedback to each preservice teacher regarding their microteaching, and also commented on their post-microteaching reflections. Although the participants were informed at the start of the semester that I was interested in their reactions to using videos, they were not explicitly told until the end of the semester that I would use their post-microteaching reflections as the primary data source. A discussion of the specifics of the study and the systematic, qualitative analysis of the data were conducted once the grades had been submitted. Given the pass/fail nature of this course, it was not anticipated that the study would cause any problems. 
Throughout the practicum course, each preservice teacher taught and video-recorded two microlessons, each lasting 25-30 minutes, to their preservice teacher peers. The first microteaching took place during Weeks 5, 6, and 7. For it, I assigned one of three skills to each preservice teacher to teach each week: reading fluency, clarification requests, and paraphrasing. The second microteaching took place between Weeks 12 and 16. For the second lesson, the preservice teachers developed a lesson for the ESL classrooms they were observing. Given that they were observing different classrooms, each preservice teacher could focus on a different, self-selected aspect. Each preservice teacher met with me to share materials and lesson plans prior to their microteaching day. On the day of the microteaching, the preservice teacher taught to her/his peers, who sat in the first two rows of the classroom. I positioned the commercial digital recorder in the centre of the classroom behind these two rows. Following the recording of the microlessons, all participants provided constructive written and oral feedback about the lesson. Immediately after the class, I uploaded the videos via YouTube and, using a private setting, shared them with the lead microteacher. The preservice teachers individually watched their videos at home, and within 48 hours submitted a mandatory $2-3$ page reflection via the institutional course management system, BBlearn, discussing (a) what went well, (b) what they would do differently, and (c) what they would integrate from their peers' lessons to improve their own work. As the practicum instructor, I responded to their reflections and provided additional formative feedback on their microteaching. The inclusion of a video-mediated reflection is based on the assumption that preservice teachers will be in a position to attend to multiple dimensions of their microteaching experience. Although it is not possible to determine if their reflections would have differed without video, it was possible to understand which dimensions they considered as a result of this exercise.

In order to gain some insights about the preservice ESL teachers' reactions to the use of video, I asked that they respond to six written prompts at the end of the semester. The first two targeted the recording process ("The video camera made me feel...," "was beneficial/problematic because..."). The next three focused on the process of watching the video ("When watching, I focused on...," "Watching my video made me feel...," "Watching was beneficial/problematic because..."). The sixth was for open-ended comments. These prompts were delivered via e-mail after grades had been submitted, to minimize conflicts of interests and to access more genuine feelings about this tool for teacher education purposes.

\section{Data Analysis}

The data for this study consisted of the two post-microteaching reflections from each preservice teacher and the e-mailed responses to the prompts asking about the implementation of videos. The preservice teachers' data were 
analyzed according to thematic units (Braun \& Clarke, 2006). I first coded the data set in full to identify preliminary codes and themes. I identified the themes through an analysis of learner comments from their post-microteaching reflections and their end-of-semester prompts. To develop meaningful and valid themes, I adopted an iterative process. Preliminary codes were identified throughout the reflections, and these codes were then grouped into four dominant themes (see Table 1).

Table 1

Overview of themes and codes

\begin{tabular}{ll}
\hline Themes & Preliminary codes \\
\hline Teacher identity & Emotional presence; Physical presence; Teacher roles; \\
& Teacher identities; Language skills \\
Teaching practices & $\begin{array}{l}\text { Classroom management; Teacher talk; Instructions, Feed- } \\
\text { back; Use of board; Technology use }\end{array}$ \\
Teaching pedagogy & $\begin{array}{l}\text { Teaching methods; Teaching materials; Writing skills; Speak- } \\
\text { ing skills; Listening skills }\end{array}$ \\
Metacognition & Camera; Behaviors, benefits, limitations; Connections to fu- \\
& ture lessons; Comparing first and second microteaching \\
\hline
\end{tabular}

Intercoder reliability was established by a second rater, also an L2 teacher educator who had previously taught a teaching practicum in a similar program. She and I coded $20 \%$ of the data independently using the major themes. The agreement was $92 \%$. Disagreements in coding were resolved through discussion. With this information, I individually recoded the remaining $80 \%$ of the data set.

\section{Results and Discussion}

In the present context, the five preservice teachers uploaded their postmicroteaching reflections within 48 hours to the institution's virtual learning environment and course management system, BBlearn. Through a careful qualitative data analysis of these reflections and opinions, four major themes were identified, which are discussed and illustrated with supporting quotes drawn from the post-microteaching reflections below.

\section{Developing Teacher Identity}

\section{A testimony to my professional identity}

Each participant wrote that microteaching in front of her/his peers and instructor, with or without a video camera, was a source of stress. They explained, however, that they tried to conceal their nervousness and attempted, to the best of their ability, to adopt a composed "teacher" persona in front of their peers. By watching their personal videos, they saw how they managed 
to project a teacher-like image to their classmates. For instance, Akari (the Japanese participant ${ }^{2}$ ) instinctively adopted a strategy to help her imagine herself as a teacher:

I tried to be myself and not to be too nervous. I imagined myself in my Japanese classes where I know all the students and I know what I am teaching. This thinking made me calm down ... Right after my lesson, I was worried about my posture and professionalism because I was not thinking about those aspects during the lesson. However, I thought I did not look unprofessional in the video, so I felt relieved.

Her post-microteaching viewing enabled her to confirm that she looked professional, an observation that she found to be encouraging. Rumi (a participant from China), when discussing her qualifications as an ESL teacher, commented: "There are some positive sides that I found from the video. First of all, I tried my best to hide my nervousness. From the video, I didn't look nervous or unconfident as a new teacher." In addition to paying attention to their professional persona, some displayed evidence of reflection-for-action (Killion \& Todnem, 1991). Chion (from Taiwan) reported:

I watched the video and I showed it to several friends. They said that was exactly me. I think that means my appearance as a teacher was not professional enough to make a clear distinction between me and teacher in front of class ... A professional appearance will without any doubt be the focus of my next microteaching.

For some, using videos appeared to contribute to their overall confidence building and establishing future goals as language professionals. For example, Akari, who was unsure about pursuing a teaching career, commented in her final reflection:

It was a great experience to plan whole lessons and conduct them. Getting feedback both from you and my classmates was very helpful. I still feel weird to watch myself teaching in the videos, but it also provided me a lot of helpful information that I had not realized before ... I now feel more confident being a teacher than ever.

Learning to teach and the consequent development of a professional identity are long and fluid processes. The participants' comments in relation to professional identities point toward the negotiated process of appearing to be and being a language teacher. Goffman (1959) compared social interactions to theatrical performances and distinguished between two kinds of sign activity: expressions that individuals give and expressions that individuals give off. Through this lens, it appears that the preservice teachers were able to view their performance and confirm that their performance met the expectations of what real teachers do (appearing to be teachers). In sum, using videos 
as a reflective tool may have facilitated the transition between appearing to becoming in new forms of social interaction.

\section{A testimony to my non-native teacher identity}

Of the five non-native speakers of English, four commented on their English proficiency skills in the present context. For example, Ivy (from China) wrote: "I have found some grammatical mistakes in my spoken English. What's more, I did not speak very coherently. I think I need much more improvements in my spoken English. It is a problem of language instead of teaching methodology." This comment reflects her concerns with her English-language proficiency as well as an awareness that her language skills are not related to her teaching abilities. For some, the linguistic abilities appeared to be intrinsically related to their perceived teacher identity, leading them to question their own ability to teach English. Rumi, for instance, commented that the video was a reminder for her to keep working on her oral proficiency, writing, "This video reminded me that I should really keep working on my speaking proficiency. I hope my future students think that I am a qualified ESL teacher." Akari, who was also dissatisfied with her English, was able to reflect on this and see it as a learning opportunity. She shared:

My utterances had many grammatical errors ... For the next microteaching, I would like to practice more speaking. However, I do not want to memorize all the scripts for the lesson because it will make the lesson look like a presentation and it would make me too nervous. The video helped me realize how much I could improve my speaking skills.

The data suggest that videos are important tools for preservice ESL teachers. As conceptualized by Schön (1983) or Killion and Todnem (1991), reflective practices are often the outcome of subjective interpretations of classroom events because of the fleeting nature of classroom interactions and events. However, the use of video-mediated microteaching reflections enabled this group of preservice teachers to become aware of their emerging teacher identity, both their strengths and their perceived weaknesses, by providing a more objective and lasting representation of themselves. The data further suggested that non-native-speaking preservice teachers should use videos to focus on their linguistic abilities and on grammatical dimensions that may have stabilized. Although videos can draw preservice teachers' attention to dimensions of teacher identities and their linguistic proficiency, I believe it is critical that we have direct discussions of the benefits and contributions that non-native English-speaking teachers bring to the language classrooms. Furthermore, given their concerns with accent and accuracy, teacher educators should discuss the importance of clear language in English language acquisition and explore strategies that foster successful communication with ESL learners. 


\section{Mirror Effect: Practical Considerations}

In this context, the teaching practicum provides preservice teachers an opportunity to put into practice the theoretical knowledge they acquired during their coursework. Preservice teachers have read extensively about pedagogical knowledge, which can include teacher talk, pacing, sequencing, and classroom management. Video-mediated reflections appear to have provided them with more objective evidence of their classroom-based actions.

\section{My voice, my gestures: I had no idea}

Teacher talk was a frequently discussed topic. Overall, some of the preservice teachers were pleasantly surprised by their speech rate. For example, Ivy wrote: "After I watched the video, I found my merits and shortcomings ... Throughout the lesson, my rate of speech was slow and clear." Others faced the reality that they did not speak clearly: Akari was surprised to see that her voice was not as loud as she had imagined. Moreover, she came to realize that she mumbled, and she recognized that the clarity of her speech was less than optimal for ESL learners. Interestingly, some initially thought that the technology failed to capture their voice. However, they commented that they could hear their peers' voices, thus eliminating the possibility of technological glitches. Rumi explained:

I could not hear my own voice clearly. At the beginning, I thought it was my computer's problem. However, later I heard Chion's voice and I realized that my teaching voice was too low and not clear. I should, like one classmate wrote in the reflection, speak up.

Interestingly, although peers had commented on this issue, it was only through the video that she accepted that this was true.

Gestures and mannerisms became salient through videos. In his reflections, Chion asserted how gestures can help him communicate ideas to his language learners; however, he realized that gestures should have a function and, in his case, did not always appear to have one. He wrote:

I notice that I had too many unnecessary gestures; I simply kept moving my right hand back and forth. Generally, [hand movements] are gestures that people use to emphasize a point. But, it is pointless if you emphasize everything. It seems to me that I used my right hand as a metronome to control my speed of speech and intonation.

Others benefited from watching their gestures as it showed them that, contrary to their beliefs, they did not overuse gestures or act inappropriately. Rumi was happy to observe that she was not touching her hair, moving her hands aimlessly, or rubbing them uselessly. Some of the participants, however, were less enthused as they realized that they displayed potentially annoying mannerisms. Ivy commented: "I've found that my nervousness 
was shown by doing many petty actions, such as fixing my hair, pulling my clothes."

In this context, the preservice teachers tended to notice behavioural and technical aspects of their actions, a pattern in line with previous studies (Calandra et al., 2008). These aspects of learning to teach are important to preservice teachers; however, to maximize the benefits of video-mediated reflection, following Santagata (2009), it may be necessary to model the discourse of discussing their own videos so they focus on issues that relate more directly to L2 pedagogy and impact L2 learning.

\section{Classroom management: So much to consider!}

In the methodology course, the preservice ESL teachers learned about taskbased language teaching. Specifically, they explored the process of implementing pretasks, tasks, and posttasks. Each of these stages of the task cycle required that they attend to time management and instructions. From watching their own videos, some realized how timing of tasks influenced the success of task implementation and task completion. As Rumi pointed out:

From the video, I saw that I did not arrange the time very efficiently. After showing them the video clip, I could have discussed the video a little bit more. I also spent too little time on giving instructions. Finally, after giving the handout, I forgot to discuss some details of the handout ... If I teach this to ESL students, I would definitely elaborate on the handout.

\section{Integrating technology: Was it smooth?}

In the teaching practicum, preservice teachers gain pedagogical technological content knowledge (Mishra \& Koehler, 2006) and are encouraged to explore new technologies to aid the delivery of content. During their microteaching, some used the technology made available in this context (whiteboard, document camera, Internet). The preservice teachers were generally happy that they could integrate these tools into their lessons. Technology required the use of a control panel to navigate among the different tools, a task that can be intimidating. Akari struggled to switch between displaying an Internet video and her PowerPoint presentation. In watching the video, she realized that while she was able to efficiently cope with the technology, her ability to interact with her students was less optimal. She reported:

I think I did a good job not to freak out when I faced a technical difficulty. Since I have never actually used the control monitor, I was very nervous, but I was glad that I could quickly discover how it works. When I watched my video of microteaching, I realized that I did not have as much eye contact as I could have. Using a Powerpoint kind of made me feel like I was giving a presentation rather than a lecture, and it made me feel more nervous than the last time. I 
think I have to practice and get used to speaking in front [of] people with various kinds of visual aids.

As a result of microteaching, preservice teachers experienced the multiple dimensions of language teaching pedagogy that were discussed in their teaching methodology course and current practicum course (i.e., teacher talk, classroom management, sequencing, technology). Some of these aspects may be less critical than others in the bigger scheme. For example, using technology smoothly may be less important than task sequencing (especially considering that many experienced teachers are not digital natives and may have even more difficulties with technology than younger, less experienced teachers). From this, although videos proved to be a beneficial instrument enabling particpants to focus on various aspects of their teaching, the preservice teachers may also benefit from working with some rubrics that rank the relative importance of teaching practices.

\section{Pedagogical Content Knowledge}

\section{Skills in material development}

In teacher education programs, a significant amount of time is spent on language skills (e.g., reading, writing, speaking, listening). Through content courses such as psycholinguistics, second language acquisition, and sociolinguistics, preservice teachers explore social and cognitive dimensions underlying the development of these skills. During the teaching methodology and practicum courses, they develop lesson plans and materials to accomplish the task of teaching these skills. In the post-microteaching reflections, the participants examined and further reflected on how their materials enabled them to teach these important linguistic skills. One important finding was their own evaluation of the relevance of the materials to the task at hand. For instance, Ivy was working on fluency-building skills. For her task, she connected reading content to the Jazz Festival, one of the university's annual vibrant events. She reported:

After I watched my own teaching performance on the video, I found my merits and shortcomings. I indeed chose a very suitable topic and relevant reading materials, which matched well with the opening of the Jazz Festival on campus. I connected the lesson with real events on campus. For the warm-up, I told the students about the news of Jazz Festival and made a smooth transition to my lesson. In the closing, I also connected the ending with jazz, which coordinated with the beginning.

She further elaborated about her success of teaching the reading skills and later questioned how she could have done things differently, as she realized that her classmates could not recall the content of the readings after doing her timed-reading task: 
I still have a question in mind. I have taught students two reading skills to improve their reading fluency. Students practiced the two skills and finished their tasks successfully, but I am not sure whether they really understood the whole text. I set up two questions at the end of the class and many students could not understand the second question. What shall I do? Do I have to ask them to read the text again?

In addition to considering the efficacy of their teaching materials, two of the participants noticed how they did not maximize the use of their own materials. Sunny (from Taiwan) was able to notice that the instructions on the handout were not clear. Rumi not only noticed this but also made suggestions regarding how she could do it differently in the future.

After giving the handout, I forgot to discuss some details ... At that time, I was a little bit nervous and I wanted to save more time for later debate; therefore, I forgot to do this. If I teach the real students and have enough time, I would definitely elaborate on the handout. I would also give some examples to help them be clear with those terms and the process.

In sum, video-mediated reflections encouraged this group of preservice ESL teachers to examine how they taught the various core English skills and to reflect on the development and implementation of relevant pedagogical materials. This line of reflection may have long-lasting benefits to their developing knowledge base, and it is this form of critical reflection that we as teacher educators want to promote.

\section{Metacognition Functions: Thinking About the Camera}

\section{Enhancing learning through repeated viewings}

Teaching happens very fast and, given the number of events that unfold in a single lesson, recalling what happened during the lessons can reflect subjective interpretations. Videos provide a record of the events that can help them reflect on their progress on multiple occasions. For instance, after her second microteaching, Sunny returned to her first video and compared her teacher talk in the two sessions. She explained: "After class, I watched the video and checked how I did. I also compared it with the last time. I found that I have improved. I did not say so too many times." Ivy not only saw the benefits of recording her microteaching lessons for her current professional development, but also saw how keeping a record of her lessons could be used for professional reasons. She wrote: "I can see my own teaching performance on the video repeatedly to make reflections. Also, I can attach it to my CV in the future. It is really amazing." Finally, Rumi explained that real changes may not occur "unless they watch again and again." 
In addition to viewing their videos alone, some also reported watching their video with others to get outsiders' perspectives about the teaching event. For example, Chion taught a lesson about paraphrasing skills. He felt confident that his materials and instructions were clear. Yet his peers' feedback indicated otherwise. Puzzled by that feedback, he decided to share the video with friends outside the practicum to see how they felt about the task materials. He commented: "I showed the video and handouts to my friends, and they got it pretty well." Despite being aware of some difficulties communicating the instructions for his tasks, Chion continued to receive similar feedback during his second microteaching. He writes that in the future he will

reduce the amount of lecture and increase the amount of group work. In this way, I can 'slow down' the progress of the lesson and allow students more time to comprehend the lesson and more chances to cooperate with peers.

It appears as though videos provide opportunities for ongoing reflective practices and provide motivation for trying new techniques.

In sum, the participants benefited from video-mediated reflections and saw the potential for learning through repeated viewing.

(Sherin, 2004; Storeygard \& Fox, 1995; Zhang et al., 2011)

\section{Emerging attitudes toward cameras}

From a pedagogical perspective, using a camera may facilitate the process of reflection. However, it is important to understand how students felt about using the camera. In the present context, the use of a camera was perceived as a positive pedagogical tool. Akari, for example, wrote: "I really liked the idea of video-recording our microteaching lessons. I was embarrassed at first, but it tells me a lot about myself." Ivy also shared this view and said: "I really appreciate the valuable experience of doing microteaching this way."

However, some of the comments suggested that they need to learn how to be better in dealing with the camera itself. For example, Ivy mentioned that "I should also study how to behave in front of a camera, how to make the videotaping more professional. I found that sometimes I was out of the camera, I should learn where to stand." These comments should quickly be discussed with the preservice teachers in order to clarify the purpose of the recordings. In fact, standing in front of the camera should not be of great importance, and is certainly not a distraction. Rather, preservice teachers need to be reminded to move freely about the classroom and ignore the focus of the lens. They should feel comfortable attending to all the learners in the classroom and move about the space as they would in a typical classroom. 


\section{Conclusions and Future Directions}

The aim of this article was to investigate which aspects of their teaching practice preservice ESL teachers focus on while viewing their recorded microteaching. It became evident that unguided reflections promoted an exploration of an array of key dimensions, and I believe that the findings from the present study contribute to our knowledge base on reflective practices and video-mediated reflections with preservice ESL teachers from linguistically diverse backgrounds. Specifically, this is one of the first studies to integrate video-mediated practices with preservice ESL teachers who were non-native speakers. Through a qualitative analysis of five preservice teachers' postmicroteaching reflections, it was found that preservice teachers reflect productively on their linguistic abilities and on their developing teacher identities, that they attempt to make connections between theoretical knowledge and practical applications of this knowledge, that they want to learn about pedagogy, and that the cameras themselves are the subject of minimal discussion.

Second, a number of researchers in TESOL have examined issues relating to non-native ESL teachers (see, e.g., Braine, 2010, 2013; Llurda, 2005; Medgyes, 2001; Moussu \& Llurda, 2008; Pavlenko, 2003; Phillipson, 1992; Selvi, 2011). However, few studies that examine video tools with preservice, non-native speakers have considered how the act of watching themselves may reveal aspects of the participants' professional identities and linguistic abilities. While there were numerous positive and constructive comments, the study did identify that the majority of the negative comments related to the students' linguistic skills. This group of non-native English-speaking teachers appears to view native-like proficiency as better models for their students. This echoes relevant literature on the native speaker fallacy, namely that the ideal teacher is a native speaker (Phillipson, 1992). This finding has important implications for teacher education programs: it is important for preservice teachers to become aware of the growing body of work reporting on non-native ESL teachers so that they can appreciate what they bring to the language classrooms.

In the light of the present results, I offer some recommendations for including video-mediated reflection tasks in L2 teacher education programs. To facilitate the process of video-mediated reflections, teacher educators could

- include relevant literature that discusses how videos encourage an exploration of their own teaching pedagogy;

- provide feedback on individual post-microteaching reflections that pushes preservice teachers to focus on their teaching practices, on the provision of feedback, and on the delivery of their instruction;

- discuss aspects of the linguistic abilities of preservice teachers when these lead to communication breakdowns and remind them that native-like command of English, while important, will not determine their futures as ESL teachers; and 
- provide models of descriptive language that relate to their pedagogy to minimize their need to discuss the tool itself (e.g., negative comments related to how they "look" in front of a camera).

While this exploratory study with five preservice ESL teachers' experiences navigating video-mediated reflective practices for the first time provides valuable insights for preservice teachers as well as teacher educators, some limitations should be acknowledged. In the present context, the preservice teachers only had the opportunity to implement two microteaching lessons and complete two post-microteaching reflections. Second, these video-mediated reflections were mandatory assignments. As such, it is not possible to determine how preservice teachers' reflections differ with and without video. Third, the study included only five participants, representing a limited range of linguistic and cultural backgrounds. It would seem prudent to further investigate this line of inquiry with a larger population of preservice ESL teachers and include native and non-native speaking peers.

Despite these limitations, the findings from the present study have important implications for $\mathrm{L} 2$ teacher education programs. In working with preservice ESL teachers who are non-native speakers, it is important to encourage them to explore positive outcomes of their materials and teaching techniques. Building on what worked well empowers future teachers and can help build their confidence as ESL teachers. Furthermore, it was uncovered that nonnative speaking teachers talk about their linguistic skills. With the growing number of non-native English-speaking teachers and with the growing phenomenon of English as a global language, teacher educators can spend more time with native and non-native preservice teachers critically examining the affordances of being non-native speaking teachers. In sum, the findings from this exploratory study suggest that more investigation of the affordances and limitations of video-mediated reflections would positively benefit MATESOL programs that use reflective practices.

\section{Notes}

1 The practicum course included eight students, but the data from the three native speakers were not included.

2 Each participant was assigned a pseudonym.

\section{Acknowledgements}

I would like to acknowledge the dedicated preservice ESL teachers who agreed to participate in the study. Also, I would like to thank my colleagues who offered valuable insights along the way, the editing staff, and the three anonymous TESL Canada reviewers for their careful and perceptive feedback.

\section{The Author}

Dr. Caroline Payant is an assistant professor in the MA TESL program at the University of Idaho. Her areas of interests include cognitive and sociocultural aspects of language acquisition as well 
as L2 teacher education. Her work can be found in the International Review of Applied Linguistics and SSLA.

\section{References}

Akcan, S. (2010). Watching teacher candidates watch themselves: Reflections on a practicum program in Turkey. Profile, 12(1), 33-45. Retrieved from http://www.redalyc.org/articulo. oa?id=169216302003

Amobi, F. A. (2005). Preservice teachers' reflectivity on the sequence and consequences of teaching actions in a microteaching experience. Teacher Education Quarterly, 32(1), 115-130. http:// www.jstor.org/stable/23478692

Baecher, L., Rorimer, S., \& Smith, L. (2012). Video-mediated teacher collaborative inquiry: Focus on English language learners. High School Journal, 95(3), 49-61. doi: 10.1353/hsj.2012.0007

Bailey, K. M. (2006). Language teacher supervision: A case-based approach. Cambridge, UK: Cambridge University Press.

Bell, N. D. (2007). Microteaching: What is it that is going on here? Linguistics and Education, 18(1), 24-40. doi:10.1016/j.linged.2007.04.002

Benton-Kupper, J. (2001). The microteaching experience: Student perspectives. Education, 121(4), 830-835.

Borg, S. (2003). Teacher cognition in language teaching: A review of research on what language teachers think, know, believe, and do. Language Teaching, 36(2), 81-109. doi:10.1017/ S0261444803001903

Borko, H., Jacobs, J., Eiteljorg, E., \& Pittman, M. E. (2008). Video as a tool for fostering productive discussions in mathematics professional development. Teaching and Teacher Education, 24(2), 417-436.

Braine, G. (2010). Non-native speaker English teachers: Research, pedagogy, and professional growth. New York, NY: Routledge.

Braine, G. (Ed.). (2013). Non-native educators in English language teaching. New York, NY: Routledge.

Braun, V., \& Clarke, V. (2006). Using thematic analysis in psychology. Qualitative Research in Psychology, 3(2), 77-101. doi:10.1191/1478088706qp063oa

Brophy, J. (Ed.). (2004). Using video in teacher education. Boston, MA: Elsevier.

Calandra, B., Gurvitch, R., \& Lund, J. (2008). An exploratory study of digital video editing as a tool for teacher preparation. Journal of Technology and Teacher Education, 16(2), 137-153. http:// www.editlib.org/p/2349

Collins, J. L., Cook-Cottone, C. P., Robinson, J. S., \& Sullivan, R. R. (2005). Technology and new directions in professional development: Applications of digital video, peer review, and self-reflection. Journal of Educational Technology Systems, 33(2), 131-146. doi:10.2190/G9E9LCQ1-H50X-4N23

Cullen, R. (1991). Video in teacher training: The use of local materials. ELT Journal, 45(1), 33-42. doi:10.1093/elt/45.1.33

Dewey, J. (1933). How we think: A restatement of the relation of reflective thinking to the educative process. Boston, MA: D.C. Heath.

Farrell, T. S. C. (2007). Reflective language teaching: From research to practice. London, UK: Continuum Press.

Freeman, D., \& Johnson, K. E. (1998). Reconceptualizing the knowledge-base of language teacher education. TESOL Quarterly, 32(3), 397-417. doi:10.2307/3588114

Goffman, E. (1959). The presentation of self in everyday life. New York, NY: Doubleday.

Griffiths, V. (2000). The reflective dimension in teacher education. International Journal of Educational Research, 33(5), 539-555. doi:0.1016/S0883-0355(00)00033-1

He, C., \& Yan, C. (2011). Exploring authenticity of microteaching in pre-service teacher education programmes. Teaching Education, 22(3), 291-302. doi:10.1080/10476210.2011.590588

Jay, J. K., \& Johnson, K. L. (2002). Capturing complexity: A typology of reflective prac- 
tice for teacher education. Teaching and Teacher Education, 18(1), 73-85. doi:10.1016/ S0742-051X(01)00051-8

Killion, J. P., \& Todnem, G. R. (1991). A process for personal theory building. Educational Leadership, 48(6), 14-16.

Kpanja, E. (2001). A study of the effects of video tape recording in microteaching training. British Journal of Educational Technology, 32(4), 483-486. doi:10.1111/1467-8535.00215

Laycock, J., \& Bunnag, P. (1991). Developing teacher self-awareness: Feedback and the use of video. ELT Journal, 45(1), 43-53. doi:10.1093/elt/45.1

Liu, M.-H. (2012). Discussing teaching videocases online: Perspectives of preservice and inservice EFL teachers in Taiwan. Computers \& Education, 59(1), 120-133. doi:10.1016/j. compedu.2011.09.004

Llurda, E. (2005). Non-native language teachers: Perceptions, challenges and contributions to the profession. New York, NY: Springer Science and Business Media.

Loughran, J. J. (2002). Effective reflective practice: In search of meaning in learning about teaching. Journal of Teacher Education, 53(1), 33-43. doi:10.1177/0022487102053001004

Masats, D., \& Dooly, M. (2011). Rethinking the use of video in teacher education: A holistic approach. Teaching and Teacher Education, 27(7), 1151-1162. doi:10.1016/j.tate.2011.04.004

Medgyes, P. (2001).When the teacher is a non-native speaker. In M. Celce-Murcia (Ed.), Teaching English as a second or foreign language (pp. 415-428). Boston, MA: Heinle \& Heinle.

Mergler, A. G., \& Tangen, D. (2010). Using microteaching to enhance teacher efficacy in pre-service teachers. Teaching Education, 21(2), 199-210. doi:10.1080/10476210902998466

Mishra, P., \& Koehler, M. J. (2006). Technological pedagogical content knowledge: A framework for teacher knowledge. Teachers College Record, 108(6), 1017-1054. doi:10.1111/j.14679620.2006.00684.x

Miyata, H. (2002). A study of developing reflective practices for preservice teachers through a web-based electronic teaching portfolio and video-on-demand assessment program. Proceedings of the International Conference on Computers in Education (pp. 1039-1043). Washington, DC: IEEE Computer Society.

Moussu, L., \& Llurda, E. (2008). Non-native English-speaking English language teachers: History and research. Language Teaching, 41(3), 315-348. doi:10.1017/S0261444808005028

Pavlenko, A. (2003). "I never knew I was a bilingual": Reimagining teacher identities in TESOL. Journal of Language, Identity, and Education, 2(4), 251-268. doi:10.1207/S15327701JLIE0204_2

Payant, C., \& Murphy, J. (2012). Cooperating teachers' roles and responsibilities in a MATESOL practicum. TESL Canada Journal, 29(2), 1-23.

Pennington, M. C. (1992). Reflecting on teaching and learning: A developmental focus for the second language classroom. In J. Flowerdew, M. Brock, \& S. Hsia (Eds.), Perspectives on second language teacher education (pp. 47-65). Hong Kong: City Polytechnic of Hong Kong.

Phillipson, R. (1992). Linguistic imperialism. Oxford, UK: Oxford University Press.

Richards, J. C., \& Farrell, T. S. C. (2011). Practice teaching: A reflective approach. Cambridge, UK: Cambridge University Press.

Richards, J. C., \& Lockhart, C. (1996). Reflective teaching in second language classrooms. New York, NY: Cambridge University Press.

Roberts, J. (1998). Language teacher education. London, UK: Arnold.

Santagata, R. (2009). Designing video-based professional development for mathematics teachers in low-performing schools. Journal of Teacher Education, 60(1), 38-51. doi:10.1177/0022487108328485

Savas, P. (2012). Micro-teaching videos in EFL teacher education methodology courses: Tools to enhance English proficiency and teaching skills among trainees. Procedia-Social and Behavioral Sciences, 55(5), 730-738. doi:10.1016/j.sbspro.2012.09.558

Schön, D. A. (1983). The reflective practitioner: How professionals think in action. New York, NY: Basic Books.

Schön, D. A. (1987). Educating the reflective practitioner. San Francisco, CA: Jossey-Bass. 
Selvi, A. F. (2011). The non-native speaker teacher. ELT Journal, 65(2), 187-189. doi:10.1093/elt/ ccq092

Sherin, M. G. (2004). New perspectives on the role of video in teacher education. In J. Brophy (Ed.), Advances in research on teaching: Using video in teacher education (Vol. 10, pp. 1-27). Oxford, UK: Elsevier.

Sherin, M. G., \& van Es, E. A. (2005). Using video to support teachers' ability to notice classroom interactions. Journal of Technology and Teacher Education, 13(3), 475-491. http://www.editlib. org $/ \mathrm{p} / 4824$ ?nl

Sherin, M. G., \& van Es, E. A. (2009). Effects of video club participation on teachers' professional vision. Journal of Teacher Education, 60(1), 20-37. doi:10.1177/0022487108328155

Storeygard, J., \& Fox, B. (1995). Reflections on video: One teacher's story. Journal of Staff Development, 16(3), 25-29.

Tripp, T., \& Rich, P. (2012). Using video to analyze one's own teaching. British Journal of Educational Technology, 43(4), 678-704. doi:10.1111/j.1467-8535.2011.01234.x

van Es, E. A., \& Sherin, M. G. (2010). The influence of video clubs on teachers' thinking and practice. Journal of Mathematics Teacher Education, 13(2), 155-176. doi:10.11016/S14793687(03)10001-6

Zeichner, K. M., \& Liston, D. P. (1996). Reflective teaching: An introduction. Mahwah, NJ: Lawrence Erlbaum.

Zhang, M., Lundeberg, M., Koehler, M. J., \& Eberhardt, J. (2011). Understanding affordances and challenges of three types of video for teacher professional development. Teaching and Teacher Education, 27(2), 454-462. doi:10.1016/j.tate.2010.09.015 